\title{
Range Improvement Following Chaining of South Texas Mixed Brush
}

\section{J. SCIFRES, J. L. MUTZ, AND G. P. DURHAM}

Highlight: Double chaining followed by raking and stacking heavy stands of south Texas mixed brush was more effective than double chaining alone or chaining one way, based on comparative degree of brush control, range forage production, and forage consumption by livestock. In a brush stand composed primarily of honey mesquite, spiny hackberry, and lime pricklyash, double chaining followed by raking and stacking reduced woody plant densities by $88 \%$, increased oven-dry forage production by over $1,600 \mathrm{~kg} / \mathrm{ha}$, and increased forage consumption by $950 \mathrm{~kg} / \mathrm{ha}$ as compared to untreated areas a year after treatment. Double chaining alone was less effective than double chaining, raking, and stacking in promoting forage production and consumption and did not improve management efficiency. Chaining one way was not considered an effective practice.

The South Texas Plains is a resource of almost 8 million ha, most of which is utilized for livestock production. The area is characterized by a growing season of 340 to 350 frost-free days and annual rainfall of 41 to $90 \mathrm{~cm}$ (Gould, 1975). The woody plant cover of the South Texas Plains is so characteristic that the area is commonly referred to as the "brush country" of Texas. In the eastern portion of south Texas, the communities are usually stratified into an overstory of species such as honey mesquite (Prosopis glandulosa Torr. var. glandulosa), huisache (Acacia farnesiana (L.) Willd.) and live oak (Quercus virginiana Mill.) with an almost impenetrable understory of plants such as spiny hackberry (granjeno) (Celtis pallida Torr.), lime pricklyash (Zanthoxylum fagara (L.) Sarg.), lotebush (Condalia obtusifolia (Hook.) Weberb), whitebrush (Aloysia lycioides Cham.), narrowleaf forestiera (Forestiera angustifolia Torr.), and pricklypear (Opuntia sp.).

Authors are professor, research associate, and graduate research assistant, Department of Range Science, Texas A\&M University, College Station. Durham is at present employed by King Ranch, Inc., Kingsville, Texas.

The research is approved by the director, Texas Agr. Exp. Sta. as TA-12166.

This research was partially supported financially by the El Sauz Ranch, Raymondville, Texas. The authors also gratefully acknowledge the efforts of M. Brownfield, game manager, for his assistance during the conduct of the research.

Manuscript received October 18, 1975.
The dense stands of woody plants seriously reduce production of range forage; and much of the forage produced in the heavy brush stands is not accessible to livestock due to mechanical hindrance. Livestock carrying capacities have been reduced by the heavy brush cover to such an extent that ranchers have been forced to either buy additional land or to increase productivity of the land they now manage to maintain or improve their family income. Brush control is usually the initial practice in range management programs in the area.

Mechanical brush control has been used more extensively than chemical methods in south Texas due to limitations of herbicides such as 2,4,5-T [(2,4,5-trichlorophenoxy)acetic acid] in controlling the broad spectrum of mixed-brush species. Honey mesquite and pricklypear are the only species in the mixed brush stands which are controlled with 2,4,5-T at rates normally considered feasible for range improvement.

Chaining, a low-cost method which results in a minimum disturbance of soil cover, has been used extensively for range improvement since it was developed in the 1940's (Fig. 1).

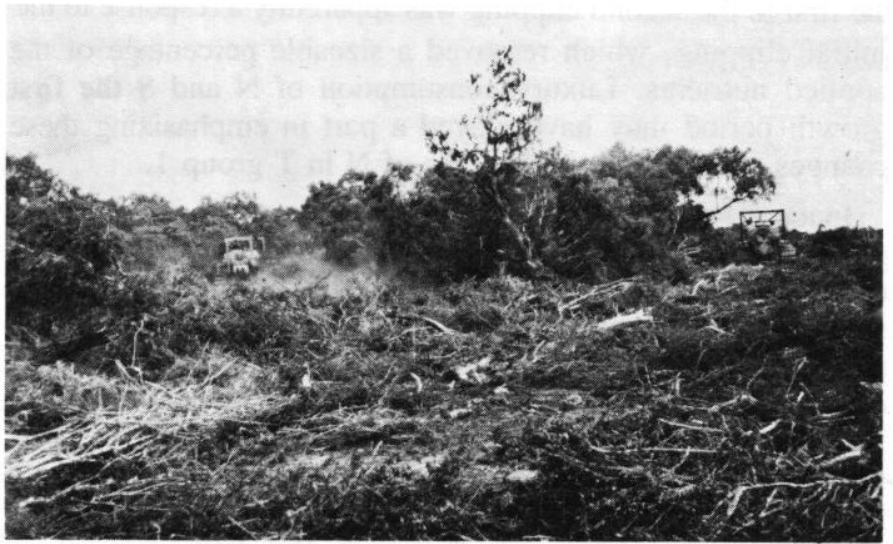

Fig. 1. Chaining is a low-cost method for reducing the cover of heavy stands of mixed brush in South Texas. 
Several approaches to chaining are employed: chain one way and leave the woody debris on the soil surface; double chain (covering the area in opposite directions) and leave the debris; or double chain followed by raking and stacking the debris and burning the stacks. The greatest value of chaining is the low initial cost of quickly knocking down, uprooting and thinning moderate to dense stands of medium to large trees (Fisher et al., 1959). Criteria for effective chaining include adequate soil moisture to assure uprooting of trees (Hoffman, undated); and, tree trunks strong enough not to bend or break before being uprooted. Double chaining may uproot $80 \%$ of the large honey mesquite trees when the moisture content of the soil is high.

Chaining has been used primarily to complement the more effective and costly brush control methods by reducing the overall cost and extending the time of control (Vallentine, 1971). Chaining at the end of the third growing season following spraying of honey mesquite is a low-cost method of increasing the degree of control over either spraying or chaining alone (Fisher et al., 1973). Chaining previously sprayed honey mesquite in the Rolling Plains of Texas made livestock much easier to manage due to reduced hindrance from standing, dead trees.

To remove brush after chaining, a brush rake or stacker rake designed to collect and pile logs, branches, and other debris may be used with a minimum of soil disturbance (Fisher et al., 1973). The stacker rake is generally used to break off, uproot, and stack small, shallow-rooted plants such as pricklypear, which grow in association with the mixed-brush (Vallentine, 1971). However, the stacker rake will not remove most deeprooted species. Chaining alone may result in extremely dense stands of pricklypear (Dodd, 1968). It removes some of the existing plant competition but scatters pricklypear stems, which readily take root and establish new stands.

The objectives of this study were to evaluate various intensities of chaining (one way; double chaining; double chaining, raking, and stacking debris) for maximum range improvement in south Texas, based on reduction of cover and density of dominant woody species and the production and extent of consumption of range forage by livestock.

\section{Materials and Methods}

Chaining treatments were applied to duplicate 20-ha plots on September 15, 1973, on a Sarita fine sandy loam site near San Perlita in Willacy County of southeast Texas about $75 \mathrm{~km}$ north of the Mexican border. Treatments included (1) chaining one way; (2) double chaining; (3) double chaining followed by raking and stacking the debris; and (4) no treatment. Plots were separated by untreated strips, approximately $45 \mathrm{~m}$ wide.

The study area was level to gently undulating, supporting a heavy stand (canopy cover $>80 \%$ ) of mixed brush dominated by large honey mesquite trees, spiny hackberry, and lime pricklyash. The Sarita fine sandy loam, slightly acid in the surface $15 \mathrm{~cm}$, became basic with increasing soil depth to $90 \mathrm{~cm}$. Organic carbon was less than $1 \%$ regardless of depth.

Ten circular grazing exclosures were established in each plot to evaluate the influence of the treatments on forage production and consumption by livestock. The exclosures were constructed of welded wire, 6-gauge, with $10-\mathrm{cm}$ openings. Exclosures about $1.5 \mathrm{~m}$ tall and covering an area about $3.42 \mathrm{~m}^{2}$ were equally spaced diagonally across each treated area and secured with metal stakes.

Consumption and yield of range forage was estimated in late August, 1974 and 1975. Sampling areas, $0.25 \mathrm{~m}^{2}$, were harvested at a 2.5 -cm stubble height inside the exclosures and in an adjacent grazed area $15 \mathrm{~m}$ from the grazing exclosure. The amount of forage in protected areas was used to estimate production. Differences between protected and grazed areas was used to estimate forage consumed by the grazing animals (Klingman et al., 1943).

Using the point-center-quarter method (Cottam and Curtis, 1956), density, canopy cover, and frequency of woody plants were also evaluated in late August, 1974 and 1975. At least 30 equally spaced points, on a diagonal line across each plot, were used to determine the vegetation attributes. An importance value index was developed by summing the relative density, canopy cover, and frequency of each woody species in each treatment.

\section{Results and Discussion}

\section{Brush Response}

Chaining one way and double chaining reduced the density of live woody plants by 39 and $47 \%$, respectively, as compared to the untreated area 2 years after treatment (Table 1). Woody plant densities had not changed significantly by 2 years after treatment. Double chaining followed with raking and stacking reduced the woody plant densities to about $13 \%$ of that on untreated areas (Fig. 2). The brush rake aided in uprooting many woody plants which were only pulled over by the chaining. Soil moisture conditions were favorable for effective chaining. However, of the species present, only honey mesquite had trunk diameters large enough to allow a high percentage of plants to be completely uprooted. Most of the honey mesquite trunks were
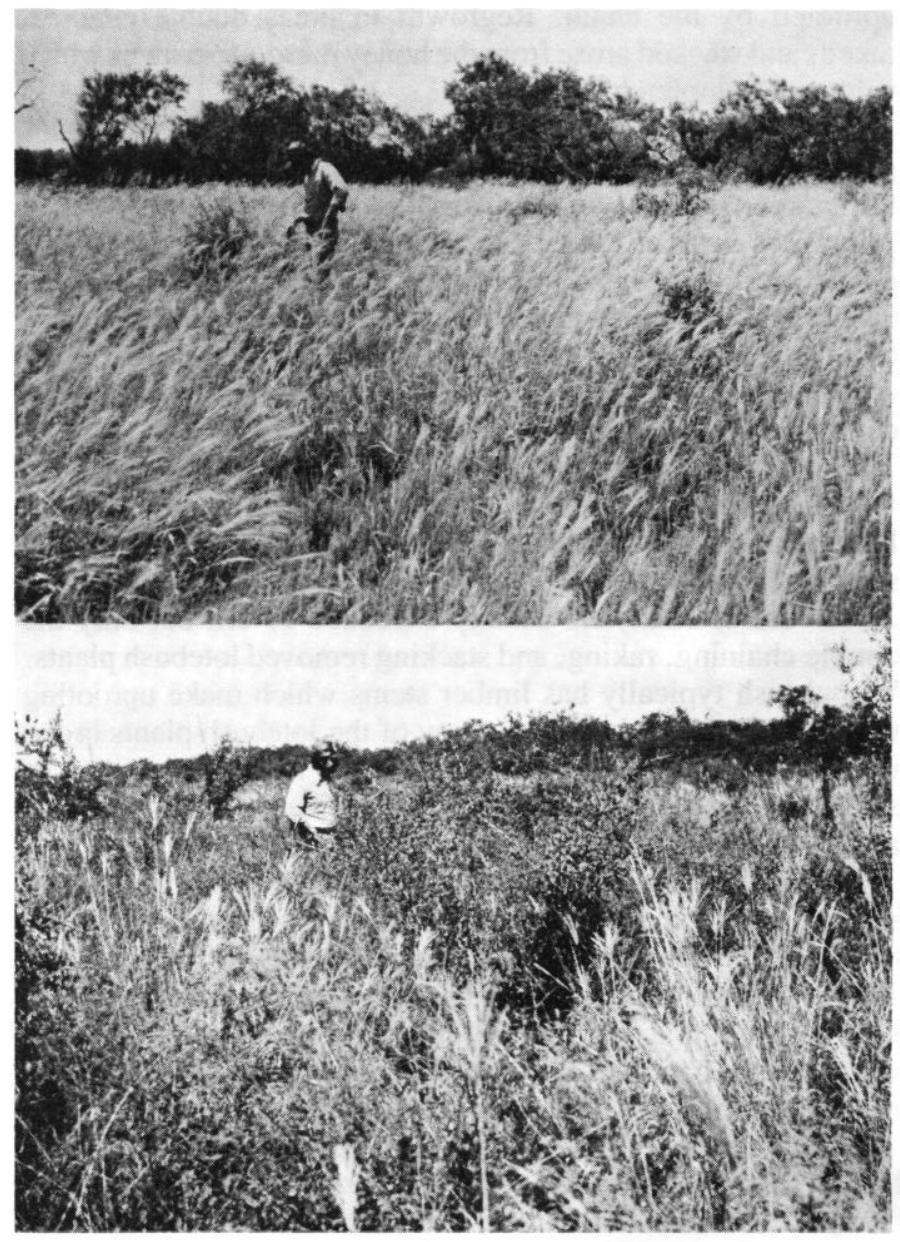

Fig. 2. Grass response to double chaining, raking, and stacking (upper) mixed brush was much more pronounced than with chaining one-way (lower). Also, differential brush control levels and amounts of woody debris left on the land influenced management efficiency following various chaining treatments. 
Table 1. Density (plants/ha) of major woody species approximately 2 years following various chaining treatments on September 15, 1973, of mixed-brush on a Sarita fine sandy loam near San Perlita, Texas.

\begin{tabular}{|c|c|c|c|c|}
\hline \multirow[b]{2}{*}{ Species } & \multicolumn{4}{|c|}{ Chaining treatments } \\
\hline & None & One way & Double & $\begin{array}{l}\text { ouble, rake } \\
\text { and stack }\end{array}$ \\
\hline Honey mesquite & 382 & 281 & 235 & 61 \\
\hline Spiny hackberry & 364 & 216 & 398 & 84 \\
\hline Lime pricklyash & 660 & 231 & 110 & 30 \\
\hline Associated species ${ }^{a}$ & 26 & 143 & 10 & 9 \\
\hline Total & 1,432 & 871 & 753 & 184 \\
\hline
\end{tabular}

${ }^{\mathrm{a}} \mathrm{A}$ mixture of lotebush, huisache, whitebrush, and narrowleaf forestiera.

greater than $20 \mathrm{~cm}$ in diameter and many were single-stemmed trees. Chaining one way and double chaining reduced the density of honey mesquite by 26 and $38 \%$, respectively, whereas double chaining followed by raking and stacking the debris reduced the density by $84 \%$ as compared to untreated areas. Originally, honey mesquite trees were estimated to exceed $8 \mathrm{~m}$ tall. Regrowth of honey mesquite in areas chained one way or double chained averaged $1.7 \mathrm{~m}$ at 2 years after treatment. At the same time, regrowth in areas double chained, raked, and stacked averaged $1.2 \mathrm{~m}$. Most honey mesquite regrowth following one-way or double chaining was the result of lateral branching from decumbent trunks pulled over but not uprooted by the chain. Regrowth in areas double chained, raked, and stacked arose from the honey mesquite crowns which were not completely uprooted.

Lime pricklyash was the most abundant woody species on the study area (Table 1). It was uniformly distributed and many of the plants were $4.5 \mathrm{~m}$ tall. Usually, the main stems of lime pricklyash were at least $12 \mathrm{~cm}$ in diameter. Thus, most of the plants were uprooted even by the less intensive treatments. One-way chaining reduced the density of lime pricklyash by $65 \%$. Double chaining reduced the density by $83 \%$, whereas the double chaining followed by raking and stacking reduced the density of lime pricklyash by $95 \%$.

Pretreatment densities of associated species (huisache, lotebush, narrowleaf forestiera, and whitebrush) were changed little by one way or double chaining. Most lotebush plants in the study area were relatively large, exceeding $4 \mathrm{~m}$ tall in many cases. Trunk diameters usually exceeded $15 \mathrm{~cm}$ but only the double chaining, raking, and stacking removed lotebush plants. Whitebrush typically has limber stems which make uprooting with a chain unlikely. Since many of the lotebush plants broke under the chain and no whitebrush were removed, control of such associated species by the more intense treatment was attributed to the raking operation.

Although chaining treatments reduced the density of most species, differential reaction among the species caused posttreatment communities to differ considerably in composition. This is an important consideration in developing followup range improvement practices. Therefore, an importance-value index was used to compare the primary brush species a year after installation of the various treatments (Table 2).

Regardless of treatment, the importance-value index for honey mesquite changed little (Table 2), indicating that although each additional treatment decreased the density, frequency, and size of honey mesquite, it remained an important component of the woody plant community. The relative importance-value index for lime pricklyash decreased with each additional treatment except for double chaining, raking, and
Table 2. Importance-value indexes for major woody species at 1 and 2 years following chaining on September 15, 1973, of mixed-brush on a Sarita fine sandy loam near San Perlita, Texas. ${ }^{a}$

\begin{tabular}{|c|c|c|c|c|}
\hline \multirow[b]{2}{*}{ Species } & \multicolumn{4}{|c|}{ Chaining treatment } \\
\hline & None & One way & Double & $\begin{array}{c}\text { Double } \\
\text { rake } \\
\text { and stack }\end{array}$ \\
\hline \multicolumn{5}{|l|}{ First year after treatment } \\
\hline Honey mesquite & 102 & 87 & 78 & 111 \\
\hline Spiny hackberry & 72 & 84 & 171 & 141 \\
\hline Lime pricklyash & 117 & 69 & 45 & 45 \\
\hline Associated species ${ }^{\mathbf{a}}$ & 9 & 60 & 6 & 3 \\
\hline \multicolumn{5}{|c|}{ Second year after treatment } \\
\hline Honey mesquite & 102 & 90 & 78 & 93 \\
\hline Spiny hackberry & 72 & 81 & 159 & 144 \\
\hline Lime pricklyash & 117 & 81 & 30 & 42 \\
\hline Associated species ${ }^{b}$ & 9 & 48 & 33 & 21 \\
\hline
\end{tabular}

Importance value is the sum of relative frequency, relative canopy cover, and relative density.

$\mathrm{b}_{\mathrm{A}}$ mixture of lotebush, huisache, whitebrush, and narrowleaf forestiera.

stacking. Prior to treatment, honey mesquite and lime pricklyash were essentially of equal importance, with spiny hackberry less important in the mixed-brush stand. Chaining treatments decreased the importance of lime pricklyash and increased the relative importance of spiny hackberry. As treatment intensity was increased, there was a trend toward increased importance of spiny hackberry. Thus, spiny hackberry may become the dominant brush problem on this site following chaining.

\section{Range Forage Response}

Primary grass species following chaining treatments were multiflowered false-rhodegrass (Chloris pluriflora (Fourn.) Clayton) and knotroot bristlegrass (Setaria geniculata (Lam.) Beauv) (Fig. 2). About $71 \mathrm{~cm}$ of rainfall was received on the study area in 1973, $50 \mathrm{~cm}$ in 1974, and $60 \mathrm{~cm}$ had occurred from January 1 to August $31,1975$.

Grass production increased with intensity of mechanical treatment (Table 3). At 1 and 2 years after treatment, areas double chained or double chained, raked, and stacked produced significantly more herbaceous growth than untreated areas or those chained one way (Fig. 2). Areas chained one way produced no more grass than those untreated, probably due to the high ground cover from woody debris.

Forage consumption from the area double chained, raked, and stacked was greater than that from areas receiving other

Table 3. Oven-dry grass production (kg/ha) differences at approximately 1 and 2 years after applying various chaining treatments to mixedbrush on September 15, 1973, near San Perlita, Texas. a

\begin{tabular}{lccc} 
& \multicolumn{3}{c}{ Chaining treatment } \\
\cline { 2 - 4 } Year and & None & One way & Double \\
\hline First year & & & \\
Double, rake and stack & $1,632^{*}$ & $1,504^{*}$ & 338 \\
Double & $1,294^{*}$ & $1,165^{*}$ & \\
One way & 128 & & \\
Second year & & & \\
Double, rake and stack & $2,599^{* *}$ & $1,830^{*}$ & 680 \\
Double & $1,918^{*}$ & $1,150^{*}$ & \\
One way & 769 & & \\
\hline
\end{tabular}

aifference calculated as production from treatment in row minus that in column. *Significant at the $95 \%$ level.

$* *$ Significant at the $99 \%$ level. 
Table 4. Difference ( $\mathrm{kg} / \mathrm{ha}$, oven-dry) in grass consumption at approximately 1 and 2 years after applying various chaining treatments to mixed-brush on September 15, 1973, near San Perlita, Texas. ${ }^{a}$

\begin{tabular}{lccc}
\hline \multirow{2}{*}{$\begin{array}{l}\text { Year and } \\
\text { chaining treatment }\end{array}$} & None & One way & Double \\
\hline First year & & & \\
Double, rake and stack & $951^{*}$ & $1,149^{*}$ & $876^{*}$ \\
$\begin{array}{l}\text { Double } \\
\text { One way }\end{array}$ & 76 & 273 & \\
Second year & 198 & & \\
Double, rake and stack & $1,529^{* *}$ & $792^{*}$ & $557^{*}$ \\
$\begin{array}{l}\text { Double } \\
\text { One way }\end{array}$ & $972^{*}$ & 235 & \\
\hline
\end{tabular}

a Difference calculated as utilization of grasses from treatment in row minus that in column.

*Significant at the $95 \%$ level.

**Significant at the $99 \%$ level.

treatments (Table 4). The year after treatment, consumption in areas that were double chained, raked, and stacked increased by $876 \mathrm{~kg} / \mathrm{ha}$ when compared to the areas that were double chained. The raking and stacking removed most of the fallen debris resulting in increased accessibility of forage to the livestock.

The winter following the double chaining, raking, and stacking, the stacks were burned. The stacks covered areas 15 to $20 \mathrm{~m}$ wide, were from 250 to $300 \mathrm{~m}$ apart, and extended the length of the treated area. Areas supporting the stacks were bare into the spring following burning. By late summer, the areas affected by the burned stacks were covered by common Bermudagrass (Cynodon dactylon (L.) Pers.). Common Bermudagrass was recognized by Scifres and Mutz (1975) as an initial stabilizer following excessive disturbance of rangeland in the Coastal Prairie. It is expected that the burned areas will eventually support species such as multi-flowered false rhodegrass, if secondary succession is allowed to proceed without additional disturbance.

\section{Literature Cited}

Cottam, G., and J. T. Curtis. 1956. The use of distance measures in phytosociological sampling. Ecology 37:451-460.

Dodd, J. D. 1968. Mechanical control of pricklypear and other woody species on the Rio Grande Plains. J. Range Manage. 21:366-370.

Fisher, C. E., C. H. Meadors, R. Behrens, E. D. Robinson, P. T. Marion, and $H$. L. Morton. 1959. Control of mesquite on grazing lands. Texas Agr. Exp. Sta. Bull. 935.23 p.

Fisher, C. E., H. T. Wiedemann, C. H. Meadors, and J. H. Brock. 1973. Mechanical control of mesquite. Chap. 6 In: Mesquite: Growth and development, management, economics, control, uses. Texas Agr. Exp. Sta Res. Monogr. 1:46-52.

Gould, F. W. 1975. Texas plants. A checklist and ecological summary. Texas Agr. Exp. Sta. Misc. Pub. 585. 121 p.

Hoffman, G. O. Undated. Mesquite control. Texas Agr. Ext. Ser. Misc. Pub. 386. $10 \mathrm{p}$.

Klingman, D. L., S. R. Miles, and G. O. Mott. 1943. The cage method for determining consumption and yield of pasture herbage. J. Amer. Soc. Agron. 9:739-746.

Scifres, C. J., and J. L. Mutz. 1975. Secondary succession following extended inundation of Texas coastal rangeland. J. Range Manage. 28:279-282.

Vallentine, J. F. 1971. Range development and improvements. Brigham Young Univ. Press, Provo, Utah. 516 p. 